\title{
RESPON HASIL TANAMAN SORGUM (Sorghum bicolor L. Moench) TERHADAP PUPUK ORGANIK CAIR DAN JARAK TANAM DI JATINANGOR JAWA BARAT
}

\section{Response of Yield of Sorghum (Sorghum bicolor L. Moench) to Liquid Organic Fertilizer and Plant Spacing in Jatinangor West Java}

\author{
Ruminta*, Agus Wahyudin, dan Aditya Ramdani \\ Program Studi Agroteknologi Fakultas Pertanian Univesitas Padjadjaran \\ J1. Raya Bandung Sumedang KM 21, Jatinangor Sumedang 45363 \\ *Alamat Korespodensi :_r_ruminta@yahoo.com
}

\begin{abstract}
ABSTRAK
Tujuan penelitian adalah mempelajari pengaruh interaksi antara dosis pupuk organik cair dan jarak tanam terhadap pertumbuhan dan hasil tanaman sorgum (Sorghum bicolor L. Moench). Penelitian dilakukan di Stasiun Lapangan Fakultas Pertanian, Universitas Padjadjaran, Jatinangor Jawa Barat. Lokasi ini memiliki ketinggian sekitar 760 meter di atas permukaan laut, tipe tanah inseptisol dan tipe iklim Oldeman $\mathrm{C}_{3}$ pada tahun 2012. Penelitian ini menggunakan Rancangan Acak Kelompok (RAK) dengan pola faktorial, dua faktor perlakuan dan tiga ulangan. Faktor pertama adalah dosis pupuk organik cair yang terdiri dari tiga taraf: 1,5 1/ ha; 31 / ha; dan 6 $1 /$ ha. Faktor kedua adalah jarak tanam yang terdiri dari tiga taraf: $25 \mathrm{~cm} \times 25 \mathrm{~cm} ; 50 \mathrm{~cm} \times 25 \mathrm{~cm}$; dan $75 \mathrm{~cm} \times 25$ $\mathrm{cm}$. Pengamatan terdiri dari komponen hasil dan hasil tanaman sorgum. Hasil penelitian ini menunjukkan bahwa antara jarak tanam dan dosis pupuk cair memberikan efek interaksi terhadap berat malai sorgum. Perlakuan pupuk organik cair dengan dosis 61 / ha dan jarak tanam pada level $50 \mathrm{~cm}$ x $25 \mathrm{~cm}$ memberikan efek terbaik terhadap berat malai sorgum (94,90 g). Pengaruh mandiri jarak tanam pada level $50 \mathrm{~cm}$ x $25 \mathrm{~cm}$ memberikan hasil terbaik terhadap bobot biji per tanaman $(71,31 \mathrm{~g})$. Perlakuan pupuk organik cair dan jarak tanam memberikan efek yang sama terhadap panjang malai, berat 1000 butir, persentase bobot biji per tanaman, indeks panen, dan hasil per lahan.
\end{abstract}

Kata kunci: pupuk organik cair, jarak tanam, hasil, sorgum

\section{ABSTRACT}

The objective of research was to study the effect of interaction between dosage of liquid organic fertilizer and plant spacing on growth and yield of Sorghum (Sorghum bicolor L. Moench). Research was carried out at Agriculture Faculty Field Station, Padjadjaran University, Jatinangor West Java. The site has an altitude about 760 meter above sea level, inceptisols soil type and $C_{3}$ climate type of Oldeman in 2012. The experiment used a Randomized Block Design (RBD) with factorial pattern, two factor of treatment and three replications. The First factor was dosage of liquid organic fertilizer which consist of three levels: 1,5 l/ha; $3 \mathrm{l} / \mathrm{ha}$; dan $6 \mathrm{l} / \mathrm{ha}$. The Second factor was plant spacing consist of three levels: $25 \mathrm{~cm} \times 25 \mathrm{~cm} ; 50 \mathrm{~cm} \times 25 \mathrm{~cm}$; and $75 \mathrm{~cm} \times 25 \mathrm{~cm}$. Observations consist of components of yield and yield of sorghum plants. The results of this experiment showed that between plant spacing and dosage of liquid fertilizer give an interaction effect to panicle weight of sorghum. Treatment of liquid organic fertilizer at dosage $6 \mathrm{l} / \mathrm{ha}$ and plant spacing at level $50 \mathrm{~cm} \times 25 \mathrm{~cm}$ gave the best effects on panicle weight sorgum $(94,90 \mathrm{~g})$. Single effect treatment of plant spacing at level $50 \mathrm{~cm} \times 25 \mathrm{~cm}$ gave the best result to grain weight per plant $(71,31 \mathrm{~g})$. Treatment of liquid organic fertilizer and plant spacing give the same effect to panicle length, weight of 1000 grain, percentage of kernels weight per plant, harvest index, and yield per field.

Key words: liquid organic fertilizer, plant space, yield, sorgum

\section{PENDAHULUAN}

Pengembangan tanaman serelia anternatif selain padi sangat penting untuk menunjang pengembangan diversifikasi pangan dari bahan non beras. Salah satu diantara tanaman serelia alternatif yang cukup penting adalah sorgum. Sorgum (Sorghum bicolor L. Moench) adalah salah satu tanaman serelia yang potensial untuk dibudidayakan dan dikembangkan pada 
daerah-daerah marginal dan kering di Indonesia dan tergolong sebagai salah satu tanaman pangan penting dunia yang menduduki urutan kelima setelah gandum, beras, jagung, dan barley. Tanaman sorgum cukup penting baik sebagai sumber karbohidrat yang biasanya dikonsumsi dalam bentuk roti, bubur, dan minuman, maupun sebagai bahan pakan ternak misalnya hay, green chop dan silage (Sirappa, 2003; Suarni, 2012).

Sorgum memiliki potensi yang besar untuk dikembangkan di Indonesia, karena kemampuannya untuk dibudidayakan di lahan-lahan bermasalah (Mudjisihono dan Damarjati, 1987; Sumantri dkk., 1996), sehingga sorgum di Indonesia tampaknya akan menjadi sumber pangan alternatif yang cukup penting dalam rangka menunjang ketahanan pangan. Budidaya, penelitian dan pengembangan tanaman sorgum di Indonesia masih sangat terbatas, bahkan secara umum produk sorgum belum begitu populer di masyarakat, padahal sorgum memiliki potensi besar untuk dapat dibudidayakan dan dikembangkan secara komersial karena memiliki daya adaptasi luas, produktivitas tinggi, input relatif lebih sedikit, tahan terhadap hama dan penyakit tanaman, serta lebih toleran kondisi marjinal (kekeringan, salinitas tinggi dan tahan masam).

Produktivitas tanaman sorgum di Indonesia masih rendah, yaitu 3.29 ton/ha pada tahun 2001 (Sumarno dkk., 2013). Pertanaman sorgum banyak dijumpai di daerah-daerah yang memiliki curah hujan sedikit seperti di Demak dan Pati Jawa Tengah dan Bojonegoro Jawa Timur (Mudjisihono dan Damarjati, 1987). Dilihat dari produktivitasnya yang masih rendah, upaya-upaya untuk meningkatkan produksi perlu dilakukan. Teknik budidaya sorgum yang telah ada saat ini masih sangat terbatas. Teknik yang diterapkan oleh petani umumnya yaitu masih sederhana dan tingkatan masukan yang masih rendah (Mudjisihono dan Damarjati, 1987).

Pemupukan adalah usaha pemberian unsur-unsur hara yang dibutuhkan oleh tanaman dan menambahkan persediaan unsur hara di dalam tanah (Ismaeil et al., 2012). Pada umumnya petani hanya memberikan pupuk anorganik seperti urea, SP36 dan KC1. Pemberian unsur hara lainnya yang juga dibutuhkan tanaman seperti $\mathrm{Ca}, \mathrm{Mg}$ dan unsur hara mikro kurang diperhatikan, sehingga kualitas dan hasil tanaman menjadi tidak maksimal. Selain itu penggunaan pupuk kimia yang intensif telah diyakini mempunyai efek merusak terhadap tanah, air dan lingkungan serta dapat menurunkan produktivitas lahan dengan melalui penurunan kandungan bahan organik, terhambatnya aktivitas mikroorganisme dalam tanah dan berkurangnya kapasitas suplai hara tertentu (Subagyo dkk., 2004). Oleh karena itu perlu 
menambahkan pupuk lain yaitu pupuk organik (Lithourgidis et al., 2007). Pupuk organik mampu meningkatkan produktivitas dan hasil pertanian secara berkesinambungan, pupuk organik juga merupakan pupuk yang ramah lingkungan dan mengandung berbagai macam unsur hara mikro yang dibutuhkan tanaman. Pupuk organik tidak meninggalkan efek residu pada tanah dan lingkungan bila digunakan secara terus menerus (Syarif, 1989; Hardjowigeno, 2003).

Salah satu jenis pupuk organik yang biasa digunakan adalah Pupuk Organik Cair (POC) yaitu ekstrak bahan organik yang sudah dilarutkan dengan pelarut seperti air, alkohol dan minyak. POC mempunyai kandungan unsur hara makro dan mikro yang dapat mengatasi kekurangan unsur hara yang ketersediaannya di dalam tanah terbatas (Nirmala, 2013). POC juga mengandung senyawa asam humat dan fulvat yang merupakan sisa pembakaran bahan organik berkadar lignin tinggi sehingga relatif efisien terhadap pelapukan dan berperan penting dalam proses agregasi dan retensi hara sehingga tanah menjadi gembur, serta mencegah kehilangan hara melalui pencucian. POC dapat memperbaiki tanah melalui peningkatan populasi mikroba tanah serta suplai hara yang cukup, efektif dan efisien bagi tanaman karena konsentrasi dan dosisnya dapat ditentukan. Pemberian POC menyebabkan perubahan sifat fisik (memperbaiki struktur, aerasi dan kemampuan tanah untuk menahan air tanah), kimia (mempercepat humifikasi, mineralisasi bahan organik dan membuffer perubahan $\mathrm{pH}$ tanah) dan biologis tanah (meingkatkan populasi aktivitas dan diversitas mikroba tanah) yang secara langsung berpengaruh terhadap laju pertumbuhan tanaman (Musnawar, 2002).

Penambahan unsur hara yang tepat jika tidak disertai dengan jarak tanam yang tepat akan mengakibatkan terjadinya kompetisi antar tanaman terhadap unsur hara tersebut, sehingga pertumbuhan dan hasil sorgum menurun dan penambahan unsur hara menjadi tidak optimal. Pengaturan jarak tanam merupakan salah satu upaya manajemen terhadap tanaman, agar kanopi dan akar tanaman dapat memanfaatkan faktor lingkungan secara optimal. Pengaturan jarak tanam erat kaitannya dengan kepadatan populasi. Populasi tanaman merupakan salah satu faktor yang menentukan hasil tanaman. Hal ini dikaitkan dengan adanya persaingan dalam penggunaan hara, air, cahaya, dan ruang tumbuh. Oleh karena itu penerapan teknologi dalam budidaya sorgum salah satunya dengan penentuan jarak tanam dan pemupukan tepat guna yang sesuai dengan kebutuhan tanaman agar dapat mencapai tingkat produktifitas yang maksimal. 
Tajuk tanaman dan perakaran menentukan jarak antar tanam yang berkaitan dengan penyerapan sinar matahari dan penyerapan unsur hara oleh tanaman, sehingga akan mempengaruhi pertumbuhan dan produksi tanaman. Tanaman dengan jarak yang lebih lebar mendapatkan sinar matahari dan unsur hara yang cukup karena persaingan antar tanaman lebih kecil, sedangkan tanaman dengan jarak tanam yang sempit menyebabkan adanya persaingan diantara tanaman dalam hal cahaya, unsur hara, dan air. Seperti hasil penelitian Simanjuntak dkk. (2016) dan Ruminta dkk. (2017) menunjukkan bahwa jarak tanam yang lebih sempit menurunkan produksi dibandingkan jarak tanam yang lebih lebar pada tanaman pangan. Tujuan pengaturan jarak tanam bertujuan memberikan kemungkinan tanaman untuk tumbuh dengan baik tanpa mengalami persaingan dalam hal pengambilan air, unsur hara dan cahaya matahari (Capriyati dkk., 2014). Makin banyak jumlah tanaman per satuan luas menyebabkan presentase cahaya yang diterima oleh bagian tanaman yang lebih rendah menjadi lebih sedikit, akibat adanya penghalang masuknya cahaya oleh daun-daun diatasnya. Jumlah cahaya yang diterima tanaman sangat dipengaruhi oleh tingkat kerapatan tanaman dan berkurangnya cahaya pada tanaman mengakibatkan terbatasnya proses fotosintesis sehingga hasil per tanaman menurun. Goldsworthy and Fisher (1996) menyatakan bahwa pada tingkat kerapatan tanaman yang tinggi, ukuran tanaman sangat berkurang dan kedalaman perakaran juga berkurang. Hal ini akan menyebabkan tidak terserapnya unsur hara yang terdapat jauh di bawah jangkauan daya isap akar.

Informasi hasil penelitian mengenai dosis pupuk organik cair dan jarak tanam yang tepat serta kemungkinan terjadinya pengaruh interaksi terhadap tanaman sorgum belum banyak diketahui, oleh karena itu dilakukan penelitian mengenai hal tersebut yang hasilnya disajikan dalam artikel ini.

\section{METODE}

Penelitian ini menggunakan tanaman sorgum varietas Unpad 1.1 dari koleksi Laboratorium Pemuliaan Tanaman Fakultas Pertanian UNPAD dan pupuk organik cair (POC) merk NASA yang dilakukan di lahan tadah hujan dataran medium Jatinangor Sumedang Jawa Barat dengan ketinggian tempat $\pm 760 \mathrm{~m}$ diatas permukaan laut (dpl), tipe curah hujan $\mathrm{C}_{3}$ menurut klasifikasi Oldeman (Oldeman, 1975), dan jenis tanah ordo Inceptisol. Metode percobaan menggunakan Rancangan Acak Kelompok (RAK) dengan pola faktorial. Perlakuan terdiri dari dua faktor dan masing-masing faktor terdiri dari tiga taraf. Faktor pertama adalah pengurangan dosis POC (I) dengan 3 taraf yaitu P1 (1.5 1/ha); P2 (3 1/ha); dan $\mathrm{p}_{3}$ 
(6 1/ha). Faktor kedua adalah jarak tanam dengan 3 taraf yaitu $\mathrm{J} 1(25 \mathrm{~cm} \times 25 \mathrm{~cm}) ; \mathrm{J} 2$ $(50 \mathrm{~cm} \times 25 \mathrm{~cm})$; dan $\mathrm{J} 3(75 \mathrm{~cm} \times 25 \mathrm{~cm})$. Pengolahan lahan, penanaman, pemeliharaan, penyiangan, dan pengairan tanaman sorgum untuk semua perlakuan dibuat seragam sedangkan pemupukan POC dan jarak tanam tanaman Sorgum diseuaikan dengan perlakuan. Perlakuan POC diberikan satu minggu sebelum tanam. Pengamatan terdiri dari komponen hasil dan hasil tanaman sorgum yaitu panjang malai, bobot malai per rumpun, bobot 1000 biji, bobot biji per tanaman, bobot biji per petak, bobot biji per hektar, rendemen perontokan biji, dan indeks panen. Pengaruh perlakuan diuji statistik menggunakan Software SPSS 17 dengan Uji $\mathrm{F}$ pada taraf $5 \%$ dan perbedaan nilai rata-rata perlakuan diuji dengan menggunakan Uji Duncan Multiple Range test pada taraf nyata 5\%

\section{HASIL DAN PEMBAHASAN}

\section{Komponen Hasil}

Hasil analisis statistik pengaruh jarak tanam dan dosis pupuk organik cair terhadap panjang malai dan bobot 1000 biji dapat dilihat pada Tabel 1. Pengaruh perlakuan terhadap panjang malai dan bobot 1000 biji menunjukkan hasil yang tidak berbeda nyata. Pengaruh efek mandiri jarak tanam dan dosis pupuk organik cair terhadap panjang malai dan bobot 1000 biji tidak menunjukkan pengaruh yang berbeda nyata namun demikian ada indikasi bahwa panjang malai pada perlakuan $\mathrm{J} 3(75 \mathrm{~cm} \mathrm{x}$ $25 \mathrm{~cm})$ dan perlakuan P3 (61/ha) memiliki nilai sedikit lebih baik dibandingkan perlakuan lainnya, serta bobot 1000 biji perlakuan $\mathrm{J} 2(50 \mathrm{~cm} \times 25 \mathrm{~cm})$ dan perlakuan P1 (1,51/ha) memiliki nilai lebih baik diantara perlakuan lainnya.

Panjang malai tidak terdapat pengaruh nyata dari perlakuan diduga ketersediaan unsur nitrogen yang cukup untuk perkembangan malai pada setiap tanaman. Unsur nitrogen berpengaruh pada awal masa reproduktif tanaman yaitu untuk perkembangan tangkai malai (Ahmed et al., 2010). Ukuran malai akhir yang ditunjukan oleh jumlah floret yang fertil, sangat berhubungan dengan ukuran tanaman dan laju penimbunan bahan kering. Kenaikan fotosintesis sebelum diferensiasi floret meningkatkan jumlah floret fertil (Goldsworthy and Fischer, 1996). Floret fertil sangat berhubungan dengan proses fotosintesis, ukuran tanaman, laju penimbunan bahan kering selama tahap perkembangannya dan lamanya waktu untuk inisiasi floret. Fotoperiodisme dan suhu lingkungan sekitar juga mempengaruhi pembentukan floret, suhu panas memperpendek lamanya inisiasi floret dan dengan demikian dapat menurunkan jumlah floret yang terbentuk serta berpenaruh terhadap panjang malai akhir (Goldsworthy and Fisher, 1996). 
Tabel 1. Panjang malai dan bobot 1000 biji tanaman sorgum yang diberi kombinasi jarak tanam dan pupuk organik cair

\begin{tabular}{|c|c|c|c|}
\hline \multirow{2}{*}{ Perlakuan } & \multicolumn{3}{|c|}{ Komponen hasil } \\
\hline & \multicolumn{2}{|c|}{ Panjang malai $(\mathrm{cm})$} & Bobot 1000 biji (g) \\
\hline \multicolumn{4}{|l|}{ Jarak tanam $(J)$} \\
\hline $\mathrm{J} 1(25 \mathrm{~cm} \times 25 \mathrm{~cm})$ & \multicolumn{2}{|c|}{$21,40 \mathrm{a}$} & 23,18 a \\
\hline $\mathrm{J} 2(50 \mathrm{~cm} \times 25 \mathrm{~cm})$ & \multicolumn{2}{|c|}{$21,92 \mathrm{a}$} & 24,99 a \\
\hline $\mathrm{J} 3(75 \mathrm{~cm} \times 25 \mathrm{~cm})$ & \multicolumn{2}{|c|}{$22,48 \mathrm{a}$} & $23,62 \mathrm{a}$ \\
\hline \multicolumn{4}{|l|}{ Dosis POC (P) } \\
\hline $\mathrm{P} 1(1,5$ 1/ha) & \multicolumn{2}{|c|}{$21,61 \mathrm{a}$} & $24,00 \mathrm{a}$ \\
\hline P2 $(3$ 1/ha) & \multicolumn{2}{|c|}{21,96 a } & $23,99 \mathrm{a}$ \\
\hline P3 (6 1/ha) & \multicolumn{2}{|c|}{$22,23 \mathrm{a}$} & $23,80 \mathrm{a}$ \\
\hline \multicolumn{4}{|c|}{$\begin{array}{l}\text { Keterangan: Huruf yang sama pada kolom yang sama menunjukkan hasil yang tidak berbeda } \\
\text { nyata menurut Uji Duncan 5\%. }\end{array}$} \\
\hline \multicolumn{4}{|c|}{$\begin{array}{l}\text { Tabel 2. Bobot malai tanaman sorgum yang diberi kompbinasi jarak tanam dan dosis pupuk } \\
\text { organik cair }\end{array}$} \\
\hline \multirow[t]{2}{*}{ Jarak tanam } & \multicolumn{3}{|c|}{ Dosis pupuk organik cair } \\
\hline & $\mathrm{P} 1(1,5$ 1/ha $)$ & $\mathrm{P} 2(31 / \mathrm{ha})$ & P3 (6 1/ha) \\
\hline $\mathrm{J} 1(25 \mathrm{~cm} \times 25 \mathrm{~cm})$ & $\begin{array}{c}74,36 \mathrm{a} \\
\mathrm{A}\end{array}$ & $\begin{array}{c}76,84 \mathrm{a} \\
\mathrm{A}\end{array}$ & $\begin{array}{c}94,96 \mathrm{a} \\
\mathrm{B}\end{array}$ \\
\hline $\mathrm{J} 2(50 \mathrm{~cm} \times 25 \mathrm{~cm})$ & $\begin{array}{c}84,68 \text { b } \\
\text { B }\end{array}$ & $\begin{array}{c}76,13 \text { a } \\
\text { A }\end{array}$ & $\begin{array}{c}94,90 \mathrm{a} \\
\mathrm{C}\end{array}$ \\
\hline $\mathrm{J} 3(75 \mathrm{~cm} \times 25 \mathrm{~cm})$ & $\begin{array}{c}89,47 \text { a } \\
\text { A }\end{array}$ & $\begin{array}{c}91,77 \mathrm{~b} \\
\mathrm{C}\end{array}$ & $\begin{array}{c}90,35 \mathrm{a} \\
\mathrm{A}\end{array}$ \\
\hline
\end{tabular}

Keterangan: Nilai rata-rata dalam tiap kolom yang diikuti dengan huruf kecil yang sama (arah vertikal) dan huruf kapital yang sama (arah horizontal) tidak berbeda nyata menurut Uji Jarak Berganda Duncan pada taraf 5\%.

Perlakuan pupuk organik cair (POC)

tidak memberikan pengaruh terhadap bobot 1000 biji sorgum diduga disebabkan kandungan hara $\mathrm{P}$ (phosfor) dalam POC NASA yang rendah sedangkan ketersediaan phosfor di dalam tanah cukup tersedia. Unsur P memegang peranan penting dalam pembentukan bunga, buah, dan biji. Goldsworthy and Fischer (1996) mengatakan bahwa pembentukan bunga, buah dan biji sangat dipengaruhi oleh ketersediaan fosfat. Phosfor merupakan unsur hara esensial makro yang dibutuhkan untuk pertumbuhan tanaman. Tanaman memperoleh unsur $\mathrm{P}$ seluruhnya berasal dari tanah atau dari pemupukan serta hasil dekomposisi dan mineralisasi bahan organik. Jumlah P total dalam tanah cukup banyak, namun yang tersedia bagi tanaman jumlahnya rendah hanya $0,01-0,2 \mathrm{mg} / \mathrm{kg}$ tanah (Nikus et al., 2004).

Hasil analisis statistik jarak tanam dan dosis pupuk organik cair terhadap bobot malai ditunjukkan pada Tabel 2. Terdapat interaksi antara jarak tanam dan pupuk organik cair terhadap komponen bobot malai. Hasil uji lanjut pada Tabel 2. menunjukkan bahwa perlakuan dosis POC 
1,5 1/ha dan jarak tanam $75 \mathrm{cn} \times 25 \mathrm{~cm}$ memberikan pengaruh yang berbeda nyata dengan jarak $25 \mathrm{~cm} \times 25 \mathrm{~cm}$, namun tidak berbeda nyata dibandingkan dengan jarak $50 \mathrm{~cm} \times 25 \mathrm{~cm}$. Perlakuan dosis POC $31 /$ ha dan jarak $75 \mathrm{~cm} \times 25 \mathrm{~cm}$ memberikan pengaruh yang berbeda nyata dengan jarak $50 \mathrm{~cm} \times 25 \mathrm{~cm}$ dan $25 \mathrm{~cm} \times 25 \mathrm{~cm}$. Perlakuan dosis POC 6 1/ha untuk semua jarak tanam memberikan pengaruh yang tidak nyata. Hasil terbaik untuk bobot malai diperoleh pada perlakuan $\mathrm{J} 2(50 \mathrm{~cm} \times 25 \mathrm{~cm})$ dengan dosisi POC 6 1/ha. Diduga jarak tanam tersebut cukup optimal untuk pertumbuhan malai dan biji selama fase reproduksi tanaman sorgum dan persaingan akan unsur hara tidak terlalu besar. Perlakuan POC dosis 6 1/ha dapat memenuhi kebutuhan tanaman selama fase pengisian biji dan dapat digunakan secara optimal oleh tanaman.

Bobot malai sangat ditentukan dari bobot brangkasan malai dan bulir-bulir biji yang tumbuh pada malai tersebut. Pasa fase pembentukan biji, sejumlah besar nitrogen dan fosfor serta sebagian kalium ditranslokasikan dari bagian tanaman yang lain untuk perkembangan biji (Piri, 2012). Malai juga melakukan fotosintesis, meski tidak sebesar daun. Pertumbuhan biji merupakan penyimpanan bahan dari fotosintesis yang berlangsung dalam daun dan malai, bersamaan dengan bahan yang dimobilisasi kembali dari penyimpanan sementara dalam bagian-bagian tanaman lain terutama bagian daun-daun atas dan ruas-ruas batang.

\section{Hasil Sorgum}

Hasil analisis statistik pengaruh jarak tanam dan dosis pupuk organik cair terhadap bobot biji per tanaman, bobot biji per petak, dan hasil biji per hektar dapat dilihat pada Tabel 3. Perlakuan jarak tanam memberikan pengaruh yang berbeda nyata terhadap bobot biji per tanaman. Perlakuan $\mathrm{J} 2(50 \mathrm{~cm} \times 25 \mathrm{~cm})$ memberikan pengaruh yang berbeda nyata bila dibandingkan dengan $\mathrm{J} 1(25 \mathrm{~cm} \times 25 \mathrm{~cm})$ dan $\mathrm{J} 3(75 \mathrm{~cm} \mathrm{x}$ $25 \mathrm{~cm}$ ), hal ini diduga dengan kerapatan barisan yang optimal dapat menekan persaingan unsur hara terutama $\mathrm{N}$ yang berpengaruh terhadap jumlah biji yang dihasilkan. Goldsworthy and Fisher (1996) menyatakan penyediaan nitrogen yang terkandung dalam tanah berpengaruh terhadap jumlah biji dan hasil.

Kerapatan populasi yang optimal pada tiap petak percobaan dapat menekan persaingan unsur hara terutama N. Selain itu diduga faktor lingkungan seperti struktur tanah, persediaan air menjadi faktor pembatas terhadap pertumbuhan reproduktif tanaman sorgum. Pada penelitian ini terdapat sedikit perbedaan struktur tanah dan kesuburan tanah pada setiap petak percobaan, ini erat kaitannya dengan periode pengisian biji. Lamanya pengisian biji dapat berpengaruh terhadap 
hasil biji menjelang akhir siklus pertanaman.

Hasil analisis statistik pengaruh jarak tanam dan dosis pupuk organik cair terhadap hasil biji per petak dapat dilihat pada Tabel 3. Hasil biji per petak menunjukan hasil yang tidak berbeda nyata terhadap perlakuan yang diberikan. Perlakuan jarak tanam $\mathrm{J} 2(50 \mathrm{~cm} \times 25 \mathrm{~cm})$ memberikan hasil sedikit lebih tinggi yaitu $1188,46 \mathrm{~g}$ atau $1,98 \mathrm{ton} / \mathrm{ha}$. Jarak tanam sebenarnya berkorelasi dengan populasi tanaman setiap satuan luas tanah, sehingga secara langsung ataupun tidak langsung mempengaruhi pertumbuhan dan hasil tanaman (Putra, 2011).

Hasil per petak pada berbagai perlakuan yang menunjukkan tidak ada perbedaan, ini kemungkinan disebabkan pada saat pengisian biji persediaan unsur hara di dalam tanaman sama. Bila dilihat dari data bobot biji pertanaman yang menunjukkan hasil yang berbeda nyata maka seharusnya hasil per petak pun

menjadi berbeda. Namun, karena perbedaan banyaknya populasi tanaman sorgum yang tumbuh pada satu petak, serta ukuran tiap malai maka kemungkinan besar akan mempengaruhi pada hasil per petak sehingga hasilnya tidak berbeda.

Rata-rata bobot biji per hektar pada percobaan ini lebih rendah jika dibandingkan dengan deskripsi tanaman sorgum varietas Unpad 1 yaitu 2.61 ton per ha. Rendahnya hasil tersebut kemungkinan disebabkan oleh kurangnya pasokan unsur hara, faktor lingkungan dan serangan hama di akhir siklus pertanaman. Jarak tanam yang optimal jika tidak didukung oleh persediaan unsur hara yang optimal akan membatasi produktivitas tanaman sorgum. Diduga kandungan nitrogen dan fosfor total pada saat pengisian biji kurang sehingga terjadi penurunan jumlah biji tiap malai. Penyediaan nitrogen mempunyai pengaruh utama terhadap jumlah biji dan selanjutnya hasil (Afzal et al., 2012; Ruminta dkk., 2017).

Tabel 3. Bobot Biji per Tanaman, Bobot Biji per Petak, Hasil per Hektar, dan Indeks Panen Sorgum yang Diberi Jarak Tanam dan Dosis Pupuk Organik Cair yqng Berbrda

\begin{tabular}{|c|c|c|c|c|}
\hline Perlakuan & $\begin{array}{l}\text { Bobot Biji Per } \\
\text { Tanaman (g) }\end{array}$ & $\begin{array}{c}\text { Bobot Biji Per } \\
\text { Petak (g) }\end{array}$ & $\begin{array}{c}\text { Hasil Biji per } \\
\text { Hektar (ton) }\end{array}$ & Indeks Panen \\
\hline \multicolumn{5}{|l|}{ Jarak tanam $(\mathrm{J})$} \\
\hline $\mathrm{J} 1(25 \mathrm{~cm} \times 25 \mathrm{~cm})$ & $57,82 \mathrm{a}$ & $989,51 \mathrm{a}$ & $1,65 \mathrm{a}$ & $0,39 \mathrm{a}$ \\
\hline $\mathrm{J} 2(50 \mathrm{~cm} \times 25 \mathrm{~cm})$ & $71,31 \mathrm{~b}$ & $1188,46 \mathrm{a}$ & $1,98 \mathrm{a}$ & $0,43 \mathrm{a}$ \\
\hline $\mathrm{J} 3(75 \mathrm{~cm} \times 25 \mathrm{~cm})$ & $63,91 \mathrm{ab}$ & $893,97 \mathrm{a}$ & $1,49 \mathrm{a}$ & $0,41 \mathrm{a}$ \\
\hline \multicolumn{5}{|l|}{ Dosis POC (p) } \\
\hline P1 (1,5 1/ha) & 58,33 a & $954,04 \mathrm{a}$ & $1,60 \mathrm{a}$ & $0,40 \mathrm{a}$ \\
\hline P2 (3 1/ha) & 68,86 a & $936,13 \mathrm{a}$ & $1,56 \mathrm{a}$ & $0,42 \mathrm{a}$ \\
\hline P3 (6 1/ha) & $65,85 \mathrm{a}$ & $1181,76 \mathrm{a}$ & $1,96 \mathrm{a}$ & $0,41 \mathrm{a}$ \\
\hline
\end{tabular}

Keterangan: Huruf yang sama pada kolom yang sama menunjukkan hasil yang tidak berbeda nyata menurut Uji Duncan 5\%. 
Tanaman yang mengalami kekurangan nitrogen antara penanaman dan inisiasi hanya menghasilkan malai kecil dengan cabang primer dan sekunder lebih sedikit, dan floret-floret yang nampak lebih sedikit pada kemunculan malai dibanding tanaman yang kandungan nitrogennya cukup. Kekurangan nitrogen antara inisiasi bunga dan antesis menyebabkan sebanyak 16 sampai 30 persen floret yang terbetuk gugur. Cekaman nitrogen setelah antesisi mempunyai pengaruh kecil terhadap hasil biji tetapi sangat mengurangi kadar nitrogen biji. Kekurangan nitrogen yang terus menerus, pengurangan jumlah floret yang terbentuk dan keguguran beberapa floret berikutnya, cukup mengurangi jumlah biji (Ammaji dan Suryanarayana, 2003; Amujoyegbe et al., 2007).

Faktor lain yang kemungkinan mempengaruhi hasil biji sorgum adalah lingkungan. Pada akhir atau menjelang panen terdapat beberapa malai sorgum yang busuk karena menjelang panen curah hujan yang tinggi dan hal ini menyebabkan beberapa petak percobaan mengalami penurunan hasil. Selama stadia pemasakan biji, tanaman sorgum memerlukan kondisi lingkungan yang kering agar diperoleh kualitas yang baik. Kondisi lingkungan yang kering akan mendorong proses pemasakan biji lebih cepat dan bentuk biji lebih seragam.
Uji statistik juga menunjukan bahwa pengaruh efek mandiri jarak tanam dan dosis pupuk organik cair terhadap indeks panen tidak menunjukkan pengaruh yang berbeda nyata (Tabel 3). Indeks panen digunakan sebagai suatu ukuran yang mendasari untuk pemilihan hasil tanaman yang tinggi. Nilainya akan sangat bergantung pada lamanya dan lajunya pertumbuhan relatif sebelum dan setelah antesis.

\section{KESIMPULAN}

Terdapat pengaruh interaksi antara jarak tanam dan dosis pupuk organik cair terhadap bobot malai. Jarak tanam $50 \mathrm{~cm} \mathrm{x}$ $25 \mathrm{~cm}$ dengan dosis pupuk organik cair 6 1/ha memberikan pengaruh terbaik terhadap bobot malai $(94,90 \mathrm{~g})$ per tanaman. Jarak tanam $50 \mathrm{~cm} \times 25 \mathrm{~cm}$ merupakan perlakuan terbaik untuk bobot biji pertanaman $(71,31$ g). Perlakuan jarak tanam dan dosis pupuk organik cair tidak berpengaruh terhadap panjang malai, bobot 1000 biji, rendemen kerontokan biji, indeks panen dan bobot biji per petak.

\section{DAFTAR PUSTAKA}

Afzal, M., A. Ahmad, and Au. H. Ahmad. 2012. Effect of nitrogen on growth and yield of sorghum forage (Sorghum bicolor L. Moench cv) under three cuttings system. Cercetări Agronomice în Moldova, XLV(4): $57-64$. 
Ahmed, A.G., S. Orabi and A.M. Goma. 2010. Bio-organic farming of grain sorghum and its effect on growth, physiological and yield parameters and antioxidant enzymes activity. Research Journal of Agriculture and Biological Sciences, 6(3): 270 - 279.

Ammaji, P. and K. Suryanarayana, 2003. Response of fodder sorghum varieties to different levels of nitrogen. J. Res. Angrau, 31(2): 109 - 112.

Amujoyegbe, B.J., J.T. Opabode, and A. Olayinka. 2007. Effect of organic and inorganic fertilizer on yield and chlorophyll content of maize (Zea mays L.) and sorghum (Sorghum bicolour [L.] Moench). African Journal of Biotechnology, 6 (16): $1869-1873$.

Capriyati, R., Tohari dan D. Kastono. 2014. Pengaruh jarak tanam dalam tumpangsari sorgum manis (Sorghum bicolor L. Moench) dan Dua Habitus Wijen (Sesamum indicum L.) terhadap pertumbuhan dan hasil. Vegetalika, 3(3): $49-62$.

Goldsworthy, P. R., dan N.M. Fischer. 1992. Fisiologi tanaman budidaya tropika. GMU Press, Yogyakarta.

Hardjowigeno, S. 2003. Ilmu tanah. Penerbit Akademika Pressindo, Jakarta.

Ismaeil, F.M., A.O. Abusuwar and A.M. El Naim. 2012. Influence of chicken manure on growth and yield of forage sorghum (Sorghum bicolor [L]. Moench). International Journal of Agriculture and Forestry, 2(2): 56 60.

Lithourgidis, A., T. Matsi, N. Barbayiannis, and C.A. Dordas. 2007. Effect of liquid cattle manure on corn yield, composition and soil properties. Agronomy Journal, 99(4): 1041 1047.

Mudjisihono, R. dan D. S. Damardjati. 1987. Prospek kegunaan sorgum sebagai sumber pangan dan pakan. Jurnal Penelitian dan Pengembangan Pertanian, VI(I): 1 - 5 .

Musnawar, E.I. 2003. Pupuk organik cair dan padat: pembuatan dan aplikasinya. Penebar Swadaya, Jakarta.

Nikus, O., M.A. Turk, and A.R.M. AlTawaha. 2004. Yield response of sorghum (Sorghum bicolor L.) to manure supplemented with posphate fertilizer under semi-arid Mediterranean conditions. International Journal of Agriculture \& Biology, 6(5): $894-897$.

Nirmala, R. 2013. Pengaruh konsentrasi pupuk organik cair kosarine terhadap pertumbuhan dan hasil tanaman selada (Lactuca sativa L.). Agrin, 17(2): $113-121$.

Oldeman, L. R. 1975. An agro-climatic map of java. Central Research Institute for Agriculture, Bogor. Indonesia.

Piri, I. 2012. Effect of phosphorus fertilizer and micronutrients foliar application on sorghum yield. Annals of Biological Research, 3(8): 3998 4001.

Putra, S. 2011. Pengaruh jarak tanam terhadap peningkatan hasil padi gogo varietas Situ Patenggang. Agrin, 15(1): $54-63$.

Ruminta, A. Wahyudin, dan S. Sakinah. 2017. Respon pertumbuhan dan hasil tanaman padi terhadap jarak tanam pada lahan tadah hujan dengan menggunakan pengairan intermittent. Agrin, 21(1): 46 - 58.

Ruminta, A. Wahyudin, dan M. L. Hanifa. 2017. Pengaruh pupuk N,P,K dan pupuk organic kelinci terhadap hasil Sorgum (Sorghum bicolor [Linn.] Moench) di lahan tadah hujan Jatinangor. Jurnal Kultivasi, 16(2): $362-367$. 
Simanjuntak, W., E. Purba, dan T. Irmansyah. 2016. Respon pertumbuhan dan hasil sorgum terhadap jarak tanam dan penyiangan gulma. Jurnal Agroteknologi, 4(3): 2034 - 2039.

Sirappa, M.P. 2003. Prospek pengembangan sorgum di Indonesia sebagai komoditas alternatif untuk pangan, pakan, dan industri. Jurnal Litbang Pertanian, 22(4): 133 - 140.

Suarni. 2012. Potensi sorgum sebagai bahan pangan fungsional. IPTEK Tanaman Pangan, 7(1): 58-66.

Subagyo, Suharta dan A.B. Suwanto.2000. Tanah-tanah Pertanian di Indonesia. Dalam Pusat Penelitian Tanah dan Agroklimat. Sumber Daya Lahan di Indonesia dan Pengelolaannya. PPTA. Balitbang Pertanian. Deptan Bogor.

Subagyo, H., N. Suharta, dan A. B. Siswanto. 2000. Tanah tanah pertanian di Indonesia. hlm. $21-66$.
Dalam Buku Sumber daya Lahan Indonesia dan Pengelolaannya. Pusat Penelitian Tanah dan Agroklimat, Bogor.

Sumantri, A., Hanyokrowati, dan B. Guritno. $1996 . \quad$ Prospek pengembangan sorgum manis untuk menunjang pembangunan agroindustri di lahan kering. Prosiding Seminar dan Lokakarya Nasional Pertanian Lahan Kering Beberapa Kawasan Pembangunan Ekonomi Terpadi di Kawasan Timur Indonesia. Malang, 10 - 12 Oktober 1996.

Sumarno, D.S. Damarjati, M. Syam, dan Hermanto. 2013. Sorgum inovasi teknologi dan pengembangan. Badan Penelitian dan Pengembangan Pertanian. IAARD Press, Jakarta.

Syarif, S. 1989. Kesuburan dan pemupukan tanah pertanian. Pustaka Buana, Bandung. 